\title{
Empires in the Near East and Mediterranean Regions: Steps towards Globalization?
}

\begin{abstract}
By Nuno Valério*
This paper discusses how the empires that developed in the Near East and Mediterranean regions between the 23rd century BCE and the 16th century CE represented steps towards the contemporary globalization process. The methodological approach is the one of world-systems perspective. Thus, besides the political element, economic, cultural and demographic aspects of the processes involved will be examined. The conclusion is that empires of the Near East and Mediterranean regions may be considered steps towards globalization in two ways: they contributed to the creation of crucial preconditions to contemporary globalization; and they displayed significant features that are similar to those of contemporary globalization.
\end{abstract}

\section{Introduction}

For nearly four millennia, between the 23rd century BCE and the 16th century CE, the Near East and Mediterranean regions witnessed the rise and fall of a significant number of empires. From the 16th century on, the Near East and Mediterranean regions have been gradually involved in what became the contemporary globalization process. Did the empires of the Near East and Mediterranean regions represent steps towards the globalization that followed? This is the question that this paper discusses.

The question will be approached from a world-system perspective. ${ }^{1}$ This means that not only the existence of political ties, but also the existence of economic, cultural and demographic connections among human societies will be emphasized. According to the world-system perspective, it is the very combination of relations linked to different aspects of social life that create the world-systems as large internally interdependent and externally self-sufficient spaces. As a consequence, empires will appear as just one of the elements of the merging of partial human societies into larger relevant spaces, namely the political element of such processes, which must also be examined according to the economic, cultural and demographic concomitant elements.

Section "Empires in the Near East and Mediterranean regions: an overview" presents an overview of the succession of empires that existed in the Near East and Mediterranean regions between the 23rd century BCE and the 16th century CE. Such an overview calls attention to the questions of the raise and fall of empires, and of the enlargement of the geographical scope of empires along

\footnotetext{
${ }^{*}$ Professor, ISEG, University of Lisbon, Portugal.

1. The seminal references for such approach are I. Wallerstein, The modern world-system (New York: Academic Press, 1974-1990); F. Braudel, Civilisation matérielle, économie, capitalisme 16e-18e siècles [Material civilization, economy, capitalism 16th-18th centuries] (Paris: Armand Colin, 1979); A. G. Frank and B. Gills, The World System: Five Hundred Years or Five Thousand? (London: Routledge, 1996).
} 
time, which are examined in sections "The rise and fall of empires" and "Extension of geographical scope of empires", respectively. Such an examination in turn calls attention to some features of the world-systems considered that were reproduced in the contemporary globalization process, which are examined in section "Analogies between features of empires and characteristics of the contemporary globalization process". However, this is not the only way in which empires in the Near East and Mediterranean regions may be considered steps towards globalization. They also created some crucial preconditions to the contemporary globalization process, as examined in section "Empires as preconditions to globalization". The last section, presents the conclusions, some of them under the form of questions about the possible future evolution of the globalization process.

\section{Empires in the Near East and Mediterranean Regions: An Overview}

It may be argued that an empire, in the sense of a political situation involving dominance of a human society over other distinct human societies, can only exist in civilized societies, in the sense of human societies with a differentiation of economic activities that implies the distinction between urban and rural communities, a hierarchy of social strata, and the existence of writing. As a matter of fact, less sophisticated human societies, such as those formed by homogeneous hunting-gathering, pastoral, or agricultural communities, lack the technological and institutional capacity to generate such complex political constructs. ${ }^{2}$

It is widely accepted that civilization appeared for the first time in Mesopotamia in the 4th millennium BCE. It is also widely accepted that this predates similar developments in any other part of the world, and that Mesopotamia was the core from which the new way of life expanded into the whole of the Near East and Mediterranean regions.

However, for ecological reasons, Mesopotamia was not self-sufficient in several essential products, such as timber, stone and metal ores. Thus, it is not surprising that the early steps of systematic long distance exchanges developed around the Mesopotamian core already during the 4th millennium BCE. At the same time, various city-states of Mesopotamia, namely Lagash, Kish, Umma and Erech, competed for supremacy, but only in the 23rd century BCE did king Sargon of Kish achieve effective dominance over the Mesopotamian plain and some neighbour mountain regions mainly in Eastern Anatolia. This usually called Akkadian Empire may be considered the first empire recorded in human history, as the previous unification of the Kingdom of Egypt around 3000 BCE did not involve the formation of an empire, because of the cultural

2. On this topic and the development of urban communities along human history, see L. Mumford, The City in History (Harmondsworth: Penguin, 1966), P. Bairoch, De Jericho à Mexico [From Jericho to Mexico] (Paris: Gallimard, 1985); A. Van der Woude et al. (eds), Urbanization in History: a Process of Dynamic Interactions (Oxford: Oxford University Press, 1990). 
homogeneity of the Egyptian people, and the political situation in the other civilized society existing at the time in the Indus valley is obscure.

The Akkadian Empire centred in Kish was short lived, and was followed, between the 23rd and the 18th centuries BCE, by the Sumerian Empire centred in Ur and the Amorite Empire centred in Babylon, with a similar geographical range. Then, the stage of competition was gradually enlarged to the whole of Near East. The main bids for supremacy came from the Empires of Egypt, ${ }^{3}$ the Hittites of Eastern Anatolia and the Assyrians of Northern Mesopotamia. Only between the 11th and the 7th centuries BCE were the Assyrians able to achieve intermittent supremacy. Then, competition moved to the ephemerous Babylonian and Median Empires (7th to 6th centuries BCE). The process culminated in the Persian Empire of the Achaemenids (6th to 4th centuries BCE), which extended over the whole of the Near East region, and was overwhelmed by the Macedonian Empire of Alexander (a brief episode in the 4th century BCE). The fact that the Macedonian Empire was created by a kingdom centred in the Mediterranean region rather than the Near East region witnesses the extension of trade and political connections beyond the Near East region.

There followed a period of division of political power among several competing states, namely the Hellenistic Kingdoms (4th to 2nd centuries BCE), of which the Seleucid Kingdom, extending from Anatolia to Iran, clearly deserves the empire label (the same may be said of the Ptolemaic Kingdom whenever it extended beyond its Egyptian core, namely to Palestine, Syria and Cyprus), until the whole Mediterranean world was united under the Roman Empire (2nd century BCE to 4th century CE), while most of the Near East region was dominated by the Parthian Empire (2nd century BCE to 3rd century $\mathrm{CE})$.

The replacement of the Parthian Empire by the Sassanid Empire (3rd to 7th centuries CE) in the Near East region, and the breakdown of the Roman Empire, leading to the formation of the ephemerous Western Roman Empire (4th to 5th centuries CE) and the more resilient Eastern Roman Empire (4th to 13th centuries CE), ${ }^{4}$ in the Mediterranean region ushered a new era, during which there emerged the Arab Empire (7th to 9th centuries) to replace the Sassanid Empire and a significant part of the Eastern Roman Empire. Then, the Near East regions experienced the onslaught of Turk and Mongol nomads, that created a kaleidoscopic succession of states, some of which, for their extension and heterogeneity, deserve the classification of empires, especially the Seljuk in the 11th century, the Mongol and its successor the Ilkhanate in the 13th and 14th centuries, and the Timurid avatar of the Mongol Jagatai Khanate in the 14th and 15th centuries. They were, however, short-lived, as a rule. From this

3. It is adequate to consider Egypt an empire at this epoch, because it extended into Palestine and Syria, whose peoples did not share the ethnic and cultural characteristics of the Egyptian people.

4. Notice that it is adequate from our point of view to date the end of the Eastern Roman or Byzantine Empire from the Latin conquest of Constantinople in 1204, although much weaker Byzantine states survived, retook Constantinople later in the 13th century and hold until the Ottoman conquest of Constantinople in 1453. However, this late Byzantine state had no imperial scope, ruling almost exclusively Greek peoples. 
situation, there emerged in the 16th century the East Mediterranean Ottoman Empire, and the Iranian Sefevid Empire. Meanwhile, the Western Mediterranean linked with most of the European continent in what may be called the Western Christendom, lived the so-called feudal period of decentralization, and started in the 15th century the process of enlargement of its geographical and commercial horizon that would eventually lead to the contemporary globalization process. ${ }^{5}$

For a while in the 16th century, supremacy in the Mediterranean was disputed by the Ottoman Empire and a Western counterpart, the Hapsburg Empire, but the formation of what may be called the Euro-Atlantic worldeconomy was already pushing the Near East and Mediterranean regions to a rather secondary role in what eventually became the contemporary globalization process.

This simplified overview of the succession of empires in the Near East and Mediterranean regions between the 23rd century BCE and the 16th century CE shows that the Near East and Mediterranean regions were important spaces for empire building throughout what is usually called ancient, medieval and modern epochs. However, these empires present two characteristics that call for further analytical work:

a. No matter how impressive they might look at the height of their power, all Near East and Mediterranean empires of this long period disappeared after a few centuries at most. What does explain the raise and fall of these political constructions?

b. Anyway, no matter how ephemeral empires were, their rising and falling processes were not symmetrical. This becomes especially clear when the larger and larger geographical scope of successive empires is considered. What does explain the persistent enlargement of the geographical scope of successive empires?

These two questions will be considered in turn in the following sections. ${ }^{6}$

\section{The Rise and fall of Empires}

Explanation of the rise and fall of empires differs between traditional historical approaches and modern world-system theories. Traditional historical explanations of empire building usually stress:

5. It is impossible to discuss here in detail the precise chronology of the contemporary globalization process. For an introduction to such a discussion see K. O'Rourke K. and J. Williamson, "When did globalization begin?," European Review of Economic History, no. 6 (2000); J. Williamson, "Late 19th-century globalization backlash," Journal of Economic Perspectives, 12, no. 4 (1998).

6. As general references for the previous overview, and the illustrations of the following analysis, the classical Cambridge Ancient History (Cambridge: Cambridge University Press, 2nd edition, 14 volumes, 1970-2005) and New Cambridge Medieval History (Cambridge: Cambridge University Press, 2nd edition, 7 volumes, 1995-2005), must be mentioned. 
1. Some special advantage enjoyed by the future dominant society - This advantage may take the form of geographical location, technological innovation, social organization, or some other type of advantage. Such heterogeneity raises the problem of the ad hoc character of these explanations. Is it possible to find a systematic theory behind such heterogeneity?

2. The cumulative mechanisms of empire building - Empire building appears as a process of overcoming the resistance of societies that are gradually subject to the control of the dominant society. From a purely quantitative point of view, it seems clear that additional resources provided by early conquests make it easier further enlargements of imperial frontiers. However, such reasoning leads to puzzling evidence: no empire expanded till being a world empire. How can such a contradiction be explained?

Modern world-system theories tended to shift attention to the following points:

3. The economy is the driving force behind the formation of worldsystems - As already pointed out above, it was the lack of several crucial resources in Mesopotamian lands that pushed to the development of long distance exchanges in the 4th millennium BCE. It may be argued that the gradual enlargement of the geographical scope of those exchanges was the basis for the creation of a Near East world-system in the 2nd millennium BCE; and It may also be argued that the discovery of the Mediterranean by Phoenician and Greek navigators, looking for outlets for their home wares and new and better sources for some resources, especially metallic ores, was the basis for the creation of a Mediterranean world-system in the 1st millennium BCE.

4. As soon as world-systems reach maturity, there are attempts at political unification, which eventually succeed - In other words, military endeavours follow the steps of commercial endeavours.

5. Economic and political unification triggers significant trends towards cultural homogenization, which eventually give rise to a unifying civilization - Of course, trade relations and imperial control imply a minimum of shared communication means (a lingua franca, to take an expression born in the crusader states of Eastern Mediterranean in the late medieval times) and behaviour rules. In the long run, this leads quite naturally to the mixing of particular religious world views (such as the merger of Roman and Greek pantheons that was called interpetatio in the framework of the Roman Empire) and to their replacement by a single religious world view (such as the attempt to create a unifying imperial cult in the same Roman Empire, and the later surrender of such an attempt to the rising of Christianity, transformed into Christendom in the 4th century CE). 
It may be acknowledged that both traditional and world-system approaches provide fruitful insights to the understanding of the process of empire building. Combining the two approaches, it is possible to stress that:

a. Empire building does not take place in a vacuum. It is based on previous economic steps towards world-systems. The geographical extent of such previous economic steps provides what may be called the natural limits of imperial expansion. Such natural limits may be understood, in this context, as a result of technological constraints. In economics parlance, it may be suggested that any expansionary move of an empire has marginal benefits (additional tribute and resources available) and marginal costs (additional deployment of military means and additional costs of transports and communication with new provinces). Previous trade links provide a good indicator to distinguish regions whose submission will lead to marginal benefits higher than marginal costs (which were already integrated in the world-system and will be conquered), and regions whose submission will lead to marginal costs higher than marginal benefits (which were not included in the worldsystem and will not be conquered).

b. Empire collapse may reverse the political steps towards globalization, but such reversal is not entirely symmetrical, because at least the technological bases and cultural consequences of empire building remain after the disappearance of the empire.

It is impossible to deal extensively here with the way these suggestions may be used to understand the building and decline of empires in the Near East and Mediterranean regions in the period under consideration, but some further remarks about the Roman Empire, one of the most durable and extensive of Near East and Mediterranean empires, may provide an interesting illustration of this type of explanation.

While Parthian resistance may easily explain the limits of the Roman Empire in the East, and the absence of viable transportation across the Sahara ${ }^{7}$ explains its limits in most of North Africa, it is not as easy to find the reason for Roman failure in Scotland, in the right bank of the Rhine, in most of the left bank of the Danube, or in Nubia. Comparison of marginal benefits and marginal costs of conquest, considering the intensity of previous trade relations may be a good way to attempt such an explanation.

The collapse of the Roman Empire in Western Europe eventually led to the formation of what may be called Western Christendom, which lived for several centuries the breakdown of economic interdependence and political centralization usually called the feudal period. However, improvements in transportation technology and the existence of the Christian religion as a unifying cultural framework prevented the situation to come back to the one of

7. Notice that dromedary caravans crossing the Sahara only developed during the 8th century CE. 
pre-Roman times, and created in the end the conditions to start what would become the contemporary globalization process.

\section{Extension of Geographical Scope of Empires}

Thus, the seemingly symmetrical processes of empire building and collapse hide a deep asymmetry, which allowed later empires to attain sizes undreamed of by earlier ones. Such enlargement of the geographical scope of empires must be understood both from a geographical and a social perspective.

From a geographical perspective, the crucial mechanism that supports the enlargement of the geographical scope of empires is the progress of the means of transportation. From this perspective, the Near East and the Mediterranean areas present clearly different challenges:

- The Near East is a stretch of relatively flat and fertile land (the so called Fertile Crescent, including Mesopotamia, Syria and Palestine) surrounded by seas (the Mediterranean, Black, Caspian, Persian, Arabic and Red Seas), plateaux (Anatolia, Iran, Arabia) and mountains (Taurus, Zagros), amounting to often barren or even desert land.

- The Mediterranean is a sea, or a complex of seas (Tyrrhenian, Adriatic, Aegean, etc.), surrounded by land, in the form of peninsulas (Maghreb, Iberia, Italy, Balkans, Anatolia), gulfs (Lyon, Syrte), or flat coast (Syria, Palestine, Egypt), and comprising a considerable number of islands.

As a consequence, the heart of the Near East must be travelled by land, although coastal navigation may play a useful role in the periphery (anyway, it is impossible to circumnavigate the region as a whole). Thus, the domestication of pack animals (from donkey to dromedary) and the building of roads are the key to human activities such as trade, military expeditions or missionary endeavours in this region.

Quite differently, the heart of the Mediterranean world is the Mediterranean Sea, and communication between the peoples that inhabit the surrounding lands is most easily maintained by ship. Thus, the building of suitable ships and the discovery of the Mediterranean maritime routes were the key to fulfilling the promise of a true Mediterranean world. ${ }^{8}$

The Near East and Mediterranean areas overlap in the Anatolia - Syria Palestine region. As a consequence, historical processes in the two areas interacted, at least from the second half of the first millennium BCE on, although the whole of Near East and Mediterranean areas never formed a single empire.

8. The problems of transport and communication in the Mediterranean world are one of the main subjects of the classical F. Braudel, La Méditerranée et le monde méditerranéen au temps de Philippe II [The Mediterranean and the Mediterranean world at the time of Philip II] (Paris: Armand Colin, 2 volumes, 1966). The original building of the Mediterranean world (with inevitable parallel analysis of Near East processes) is the subject of the posthumous F. Braudel, Mémoires de la Méditerranée [Memories of the Mediterranean] (Paris: Éditions de Fallois, 1998). 
From a social perspective, the crucial mechanism that supports the enlargement of the geographical scope of empires is the development of civilizations, in the sense of shared cultural structures among different peoples. Hellenism in the second half of the 1st millennium BCE and Christianity and Islam in the 1st millennium CE may be presented as civilization elements or civilizations that remained fundamental in the process of contemporary globalization.

\section{Analogies between Features of Empires and Characteristics of the Contemporary Globalization Process}

The process of empire building sketched in the previous sections suggests the first reason why Near East and Mediterranean empires were steps towards contemporary globalization: there are important analogies between some features of Near East and Mediterranean empires and some characteristics of the contemporary globalization process.

It is possible to point as the most important of these analogies the following:

1. Economic roots - The contemporary globalization process is first and above all the process of formation of a world economy, that is to say, a world-economy that is not only a complex set of interdependent heterogeneous partial economies, but gathers all partial economies of mankind into a single interdependent whole. ${ }^{9}$

2. Empire building - The decisive steps of the formation of the contemporary world economy were accompanied by attempts to build huge imperial constructions, mainly centred in Europe and stretching over the Americas (in a first phase, mainly between the 16th and 19th centuries), Africa (only the very periphery of the continent between the 15th and the 19th century; almost the whole of the continent between the last quarter of the 19th century and the mid-20th century), Asia (very tiny parts between the 16th and the 19th centuries; large parts of the continent during the 19th and first half of the 20th centuries) and the Pacific (since the late 18th century). Anyway, despite all attempts at global hegemony and the development of systematic mechanisms of international cooperation, especially international organizations since the mid-19th century, no clear trend towards a global empire ever emerged.

3. Development of elements of common civilization - Economic and political relations implied the development of shared practices and even values, formalized in international law and international declarations of principles, in spite of the fact that world-religions, developed in the framework of previous civilizations, remain the main basis of the world

9. Notice as hyphenation may be used to stress the difference between world-economies and world-systems that did not include the whole of mankind, and the world economy and the world system created by contemporary globalization. 
view of the majority of mankind (and tend to compete for global supremacy with the secularized world view that developed together with the formation of the contemporary world society).

The question of the possible evolution of the contemporary world system from this perspective will be considered again below.

\section{Empires as Preconditions to Globalization}

Before that, further reflection on the way the formation of non-global world-systems (non-global in the sense that they did not stretch over the whole world) was decisive for the formation of the contemporary world system is in order.

Empires (and systems that were linked to the building and preservation of imperial spaces such as world-economies and civilizations) were preconditions to contemporary globalization also in the sense that contemporary globalization would not be possible without the basis provided by previous world-systems.

This is a consequence of the fact that the extension of commercial links, the formation of imperial constructions and the development of civilizations are never balanced processes in the sense of involving in the same way all partial societies included. As a matter of fact, there is always some predominant society that takes the initiative to build such world-economy, empire or civilization. As it may be easily understood, such a society must have some particular characteristics that allow it to play such a dynamic role. Among these characteristics size and sophistication are undoubtly very important; and it is clear that previous world-economy, empire and civilization building in the Near East and Mediterranean regions, as presented in section "Empires in the Near East and Mediterranean regions: an overview", provided to the Western Christendom the preconditions of size and sophistication needed for the initiatives that brought about the contemporary globalization process.

It is impossible to go into much detail about this topic in the context of this paper, but it is useful to stress some points:

a. Although only some partial societies of Western Christendom (at first mainly Iberian societies; later also some societies from Northwestern Europe) became deeply involved in the process of enlargement of the geographical and commercial horizon that transformed the Western Christendom into the Euro-Atlantic world-economy (and later into the contemporary world economy), interdependence among all Western Christendom societies ensured that resources from parts of Western Christendom not directly involved in the process also contributed to it. Participation of Italian and Flemish navigators and capitalists in early Iberian explorations of the Atlantic provides a striking example that the whole breadth and the size of Western Christendom mattered for the process. 
b. The cultural background provided by old Hellenistic developments and the proselitism of the Christian religion, both of Mediterranean origin, were certainly decisive to foster Western Christendom initiatives from the 15 th century onwards.

\section{Conclusion}

From the previous sections, it becomes clear that empires of the Near East and Mediterranean regions may be considered steps towards globalization in two ways:

i. they contributed to the creation of crucial preconditions to contemporary globalization;

ii. they displayed significant features that are similar to those of contemporary globalization.

However, it may be argued that there are further significant analogies between the evolution of previous world-systems and the present situation of the contemporary world system. For instance, it was pointed out above, that in spite of the development of huge imperial constructs, no decisive trend towards a world political unification ever set up; in the same way, old world-religions, inherited from previous civilizations are still competing for dominance as world views with the secularist world view that developed together with the early steps of the globalization process. Is this just a sign that the contemporary world system has not yet reached its maturity? Or does it mean that the system has peculiar characteristics that imply (or, at least, allow for) stabilization at a stage in which no imperial power imposes its yoke over the whole world, and the formal institutions needed for globalization are agreed upon between independent states, which guarantee the autonomy of different peoples?

Of course, historical analogies are not necessarily good tools to predict the future. But, at least, we should not avoid raising questions such as:

- Will the contemporary globalization process go on to the global empire stage that an analogy with these old processes would suggest?

- Will the contemporary globalization process go on to the global civilization stage that an analogy with these old processes would suggest?

These questions are certainly worth discussing, if we want history to be a truly useful tool in illuminating a somewhat unclear future. Of course, such a discussion cannot be developed in the context of this paper. However, it is perhaps worth pointing out a few characteristics that make the contemporary world economy different from traditional world-economies:

A. The industrialization, and later tertiarization, processes imply that the contemporary world economy has an economic basis that is much more 
sophisticated than that of traditional world-economies. At the same time, the fact that, since the introduction of the telegraph, the contemporary world economy has had at its disposal means of communication that are much more rapid than the means of transport has had similar consequences.

B. The huge increases occurring in terms of population and economic activity mean that the contemporary world economy has a much greater impact on nature than did the traditional world-economies. As a consequence, the so-called ecological issues may play a very decisive role in the future evolution of the contemporary world economy.

C. The development of scientific and technological research implies that the contemporary world economy has a much greater capacity to innovate than traditional world-economies. At the same time, the spread of knowledge implies that the contemporary world economy has a much greater capacity to diffuse innovations than traditional worldeconomies. As a consequence, the potential for change is much greater.

Will these characteristics lead to a distinct path in the historical evolution of the contemporary world system? This is the crucial question that remains open (and will plausibly remain open for a long time).

\section{Bibliography}

Bairoch, P. De Jericho à Mexico [From Jericho to Mexico]. Paris: Gallimard, 1985.

Braudel, F. La Méditerranée et le monde méditerranéen au temps de Philippe II [Material civilization, economy, capitalism 16th-18th centuries]. Paris: Armand Colin (2 volumes), 1966.

Braudel, F. Civilisation matérielle, économie, capitalisme 16e-18e siècles [Material civilization, economy, capitalism 16th-18th centuries]. Paris: Armand Colin (3 volumes), 1979.

Braudel, F. Mémoires de la Méditerranée [Memories of the Mediterranean]. Paris: Éditions de Fallois, 1998.

Frank, A. G. and B. Gills. The World System: Five Hundred Years or Five Thousand? London: Routledge, 1996.

Mumford L. The city in History. Harmondsworth: Penguin, 1966.

O'Rourke K. and J. Williamson. "When did globalization begin?" European Review of Economic History, no. 6 (2000).

Van der Woude, A. et al. (editors). Urbanization in History: a Process of Dynamic Interactions. Oxford: Oxford University Press, 1990.

Various authors. The Cambridge Ancient History. Cambridge: Cambridge University Press (2nd edition, 14 volumes), 1970-2005.

Various authors. The New Cambridge Medieval History. Cambridge (UK): Cambridge University Press (2nd edition, 7 volumes), 1995-2005.

Wallerstein, I. The modern world-system. New York: Academic Press (3 volumes), 1974-1990.

Williamson, J. "Late 19th-century globalization backlash". Journal of Economic Perspectives, 12, no. 4 (1998). 
Vol. 4, No. 2

Valério: Empires in the Near East and Mediterranean Regions... 